\title{
Critique as alibi: moral differentiation in the art market
}

\author{
Suhail Malik University of London
}

\begin{abstract}
Critique takes a key role in the political economy of contemporary art's marketization. It gives substance to a moral involvement in contemporary art that is operationally central to the distinction between its primary and secondary markets. In so doing, critique serves to maintain the grip of the primary market over contemporary art. Accounting for the distinction between markets in terms of a 'spirit of capitalism' shows furthermore how, even though the primary market disparages the encroachment of neo-liberal marketization in its field of activity, in its reliance on critique it nonetheless serves to legitimize the social re-organization of capital accumulation by neo-liberalism. Critique is then identified as an alibi for marketization qua neoliberal capital accumulation. On this basis, the heightened cultural and market interests in contemporary art at precisely the moment when neo-liberalism has been a dominant economic model have to be understood as something other than just an effect of inflated asset prices and cheap credit.
\end{abstract}

It is a commonplace that the rapid expansion in the volume, depth and price levels of the artmarket in the boom years of the early mid-200os reflects the expansion and asset inflation of the growth of financial capital since the mid-1990s. In September 2007 The Art Newspaper presented a chart compiled by Art Market Research indexing how, after the collapse of the late-1980s boom in both the art market and the Dow Jones and FTSE 100 , the art market gave similar rates of returns as these stock markets from mid-1992 to 1995, smaller returns and rates of returns for 1995 to 2003 , then a relative increase in returns from art compared to the rise in stock prices from mid-2006 to mid-late 2007. Futhermore, the rate of return from art was much sharper in the period of mid-2006 to Summer 2007 than for either major equity market. The variation in how tightly or not art market returns are correlated to equities markets over the period of financialization confirms Olav Velthuis's observation that 'no economist has ever been able to prove that art prices consistently follow the stock market's upward or downward movement' (2008: 305). But the 'consistently' here depends a great deal upon the period under scrutiny. Since the recovery of the stock markets from the slump following the September 2001 attacks on the United States to the peak of the equities and art price booms in early-Summer 2007, The Art Newspaper notes that 'the artmarket has been tracking the stock markets much more closely [than before], suggesting that contemporary art [prices are] linked to the

\section{Keywords}

artistic critique contemporary art neo-liberalism primary market spirit of capitalism 
1. See, for example the advertisements for a training course on 'Investing in Art' offered by Euromoney Training (2008). The prospectus remarks that there are higher investment returns from art than equities and property over short and long terms, leading to a 'recognition of art as an investment [that] is set to grow in acceptance in the coming years'. The publicity also tellingly notes that 'the relative inefficiency of the art market offers attractive and significant opportunities to well advised investors'. It is this 'relative inefficiency' especially characterizing the primary market that is the main focus of the present discussion. For an econometric approach to art as an alternative asset class cf. Campbell (2008), who notes that there is a 'severe lack of indices... for the art market'. value of the traditional markets' (Gerlin 2007: 1). This report is of course filed in the interregnum between the exposure of the 'toxicity' of mortgagebacked securities embedded in the financial paper-asset system in the wake of the US sub-prime mortgage defaults and the drawing back of lending that catapulted the system into crisis in Summer 2008. At the time of this writing (October 2008) it is too early to tell whether the freezing of global capital liquidity known as the 'credit crunch' will have a decisive impact on artmarket prices over the medium-term, though there are obvious indications of 'nervousness' in the reported 'weaker demand' at the 2008 Frieze Art Fair (despite continued sales of art at price levels below the highest) (Reyburn 2008; Reyburn and Kazakina 2008), and modern and contemporary art being auctioned at the minimum or belowminimum presale estimates in London and New York (Boroff 2008). In any case, the tight, non-random correlation between artmarket prices and the two major equities markets of London and New York since the early 1990 s up to mid-2006 - after which, as noted, the rate of return on the art price index increased at a rate faster than that of the equities markets indicates nonetheless that art prices were increasing because they were for the most part following 'traditional markets' rather than for reasons intrinsic to contemporary art itself. Understood as an effect of what takes place on the 'more traditional markets' in both boom and bust, the artmarket has been only an 'alternative asset class' - another 'store of value' in relation to other markets.' The relation between price and art then has nothing to do with art itself or, of course, artistic value. It is only a market investment.

Even though it is arrived at through an inverted route, such a result is hardly novel. The distinction between market value and what can here be called 'art value' (acknowledging the problematic status of that term) mirrors both humanistic sentiment over the irreducible surplus of art and autonomy-models of its critical uselessness. In either case, the basic formulation is that art is irreducible to number, which governs markets. The argument of this paper is, in brief, that whatever route is taken in establishing such a distinction, it in any case upholds a political economy of contemporary art and its (signifying or asignifying) sense codified through a morality and presented as critique, and that this morality is a core feature of the social and practical organization of its marketization. Equally, it is precisely the established practices of this politicalmoral economy that are put under pressure by the increasing interest in art as an alternative asset class, exposing the necessity of establishing and distributing critical claims for contemporary art so as to secure an ideological distinction between art and its market. In doing so, such claims no less maintain the grip of the set of established cultural-moral practices of art's marketization known as the primary market. Critique is then only an alibi for one kind of political economy of marketization against another, a method for putatively refuting a marketization which it serves all too well but which cannot be acknowledged too directly without ceding the power of the market it serves to another more 'efficient' one that could readily overwhelm it in velocity and intensity of accumulation (and dispossession). The argument proceeds in three stages: first, a delineation of the key operational determinations - which are also at 
once affective, biopolitical and inter-personal criteria - of the primary market contrasted to the secondary market; second, these criteria are identified with key features of critique within art itself; third, taking up Luc Boltanski and Ėve Chiapello's characterization of 'artistic critique', it is proposed that critique does nothing against marketization and capital accumulation but, on the contrary, gives legitimacy to capital accumulation by being a central feature of art's marketization. That is, since the mid-late 1980s, the ontology and pragmatics of critique have and continue to abet capital accumulation.

The organizing distinction in kinds of value operative in the practical market-formation of contemporary art that is key here is well captured by the sociologist-economist Olav Velthuis (2005). Portraying the common ways in which the primary market demarcates how and to whom it makes sales from other kinds of art sales (even for exactly the same work), Velthuis remarks that dealers distinguish between right and wrong reasons for buying art. The grounds for the distinction are not primarily monetary or personal status. Rather,

collectors who buy for the right reasons are those who claim to be motivated by love for art, and who act accordingly. They think about art as an 'intellectual pursuit'; they have 'dialogues' with the work, want to get together with the artist, and follow the gallery in its artistic choices; they travel to openings of shows in which the artist is represented and have an interest in the artist's career.

(2005: 43)

Who the work goes to, and where, is conditioned by the collector's demonstration of care and 'love' of art. The motives of collectors are important to art dealers since these 'may affect the future biography of artworks' (2005: 43). Core to the shaping of that biography is when and how the artwork reappears on the market, which attests to how much the art is to be treated as a commodity like others (and therefore not cared for enough) or, more importantly, not:

What is crucial for art dealers is that the collectors do not consider reselling
the works they have bought, even when such resale would be profitable. In
the United States, collectors who buy for the right reasons ideally donate
(part of their collection) to museums, or, in a rare case, fund a museum of
their own. Such donations, like direct sales to museums, are attractive
because of the credibility or legitimacy they lend to an artist's oeuvre as well
as to the gallery itself; indeed, for artists and collectors, the number of works
that they either directly or indirectly manage to sell to museums is a source
of status. (2005: 43)

Primary market dealing is characterized by finding the right kinds of social value and accreditation for art values, identified with traditional humanist virtues of a heightened intellectual-affective appreciation (which would tend towards connoisseurship were it not for the frequent proclamations of subjective passion for art, expressing deeply personal 
2. There are obviously exceptions to this general characterization, such as Larry

Gagosian and Damien Hirst who have established reputations for ostentatiously trading art more as commodity than intellectualamorous object of care. Importantly though, such figures are few and far between in the 'core' contemporary art world and are understood to be doing things in a 'different way' to the usual practices that are the focus here. More tellingly yet, such trades are undertaken substantially as demonstrations of their power and centrality in the artsystem. And what is clearly demonstrated by such actions is (i) that such power and centrality is organized by money, and (ii) that through their exception to the standard and rarely public exhibition of price-valuations in the art-market these figures avow their own sovereignty in that milieu. The organization of sovereignty through money is a neo-liberal precept. care rather than cold-blooded appreciation). Taking art as a commodity understanding it primarily in terms of exchange-value for capital accumulation - is a degradation of the artwork, the dealer and the collector: ${ }^{2}$

the wrong reasons for buying art are reasons that have to do with investment, speculation, status, or, to a lesser degree, decoration. Both in the hands of status seekers who see the price as something admirable about the work, and in the hands of speculators, the artwork fails to get rid of its commodity character after leaving the commodity phase.

(2005: 44)

These 'wrong' reasons are displayed most obviously at art auctions where the focus is on the price more than any other aspect of the artwork's 'biography'. However, the auction price is one of the few occasions where the actual price of art is established in public and is common knowledge, rather than the more usual gallery practice of a nominal price, which is subject to great negotiation dependent largely on the dealer's wish to form the artwork's future biography. For artworks auctioned at headline-grabbing record-setting figures the price becomes a powerful, over-determining characteristic of the art to the detriment of its other attributes (unless, of course, that price valuation is the work's subject). As much as it has anything to do with standard notions of price reflecting value, such price-setting can of course be a rhetorical act deployed by gallerists, dealers and collectors to draw attention to this or that artist's putative importance. But in any case such over-determinations are deplored by dealers operating in the code of the primary market since 'they want to the work to function properly, to provide a good context for it, and to prevent it from becoming an object of financial speculation (...), from getting in touch with money again' (Velthuis 2005: 44). In the rhetoric, selflegitimations and declared ambitions, the primary market puts a firm distance between art and money, decontaminating it from its commodity status. The secondary market puts it back in contact with money. (It is of course the case that some if not most dealers operate in both primary and secondary markets simultaneously. Nonetheless, the analytical differentiation between markets holds in practice since the modes of operation, scripts, and play of convictions operating in either are quite distinct. Velthuis notes the different tones and kinds of justification and interest in art expressed by dealers between front-of-house and the back-room and their own private collections.)

This distinction between the right and wrong reasons for buying art is the standard and deeply set one between art and commerce, values of noble appreciation against commercial exchange for accumulation's sake. The right reasons to collect art - which everyone on the primary market must hold on to if they are going to be considered serious, and if they are to be given access to the art at all - is that it is not an open market in which anyone can enter to buy whatever they please, and certainly not one driven primarily by commercial interests. The terms 'right' and 'wrong' here are however not just procedural or methodological determinations. Understanding itself as a milieu and mode of operation which seeks to protect and cultivate art through the key category of care for it, the primary market establishes itself and its priority over the exhibition and distribution of contemporary art through a profoundly moral discourse and series of practices. This moralism is set against not 
only (i) the commercial economics of the secondary market, but also (ii) what the secondary market means in terms of the relation between art-values and market values, and it seeks to shape (iii) where and how money comes into the art world:

[i]n contrast with dealers, who [have] intimate ties to artists and collectors..., auction houses do not maintain ongoing relationships with artists, and make hardly any efforts to promote their work. Therefore dealers reproach auction houses for being exclusively profit-oriented and for being 'greedy'.

(Velthuis 2005: 86)

'Greedy' here is a judgement of over-accumulation with moral overtones. Those overtones are made explicit in another dealer's condemnation of the secondary market cited by Velthuis: 'it is a parasitic culture. [...] They have no loyalty to the long-term integrity of the art world. I think it is disgusting' (2005: 86). Like the terms 'right' and 'wrong', the terms 'integrity' and 'loyalty' are moralistic. And they are also terms of inter-personal and social-affective alliance bound to the order of 'care' (which, it is worth recalling, is for Michel Foucault the primary technique of modern power qua biopolitical governance of modern power (1978: 137ff.)). Determined affectively and passionately, the moralism commanding a certain formation of accumulation is personalized and naturalized. It is important to recognize that what is recorded as the 'inefficiencies' of a market of heavily illiquid goods from the side of market-based capital accumulation is from the side of the primary market's determinations a nexus of control over the development of the art. Which is to say: a technique of control over the development of the market and also a wish for control over the extravagant and influential power of commercial prices for rare objects at auction that disrupt the careful price-setting mechanisms and scripts of the primary market (with consequent effects on the careers of the artists and, to a lesser extent, of the dealers themselves).

The conjunction of such procedures of control with the affective-pastoral order of care permits a full identification of the operation of the primary market as a mode of Foucauldian biopower (Foucault 2007: 184). More important than this broad theoretical identification is the recognition that what is being bought and exchanged in the primary market through the trading and collecting relation is not just this or that artwork but also a bid of care into the future. It is not just the art(ist) and their 'diachronic price development' (Velthuis 2005: 83) that is being nurtured through the control of the primary market. It is also the collectors who are being nurtured through a naturalized socio-moral bond. The relation of care nurtures collectors in the implicit but necessary terms of their being an income stream but also in the explicit terms of their own cultivation through art, which is a moral claim by and for the collector organized through social function (attending to the artist) and aesthetics. In the primary market, income and cultural cultivation (Bildung) are unified through this moral claim, and the cultivation of the art(ist) is a cultivation of the collector. The primary market proposes itself as a moral engine purportedly circulating around the art (ist) but, because the engine is heavily fuelled by money, its operational core is rather the collector as a suitable moral agent.

It is this morality that is under threat if, instead of being driven by the interest in (the) art's future, investment in art is mainly an offshoot of 
investments in traditional markets, as represented by the secondary markets. This is yet another version of the obvious organization of art versus commerce reshaped as a morality versus market-forces story. Here, the moral code of the primary market and contemporary art takes an immediately heroic-political role in relation to purported dehumanizing dominant forces of capital, fitting in all too well with a prevalent anti-capitalism, anticorporate, anti-globalization politics. Velthuis identifies how, in its moral coding of its biographical development, which is also a moral coding of accumulation, the primary market is pitched against another accumulation model and is then at once a political economy:

[the] objections of art dealers to auction houses reach the core of neoliberal discourse on the market: the idea that everyone has equal access to the market, that goods are distributed freely on the basis of willingness to pay, and that no buyers and sellers are privileged or put at a disadvantage on social and cultural grounds. The logic of the artmarket is a different one. Seeking control over the biography of the work of art, dealers want to be able to decide who will own a work of art, and therefore try to undo the freedom that neoliberals associate with capitalist markets. If the artwork is sold at an equilibrium price at auction, in galleries this function of the price mechanism is deliberately restricted.

(2005: 90)

The 'open' secondary markets of the auctions and art understood as an alternative asset class attest to a neo-liberal formulation of accumulation in which 'control over the biography' of the artwork is abandoned to rapacious marketization and 'commodification' (if that is what it is - more likely, a 'marketization in order to financialize') that extends to anything and everything more or less indifferently. In its 'true' and 'proper' moralized market formation, contemporary art withstands and defies such neo-liberal tenets and nostrums. It establishes another, moral-biopolitical order of marketization more in keeping with humane, inter-personal and socially responsive criteria - not least, the criteria of care as a bid into the future.

This is where and how critique takes its part in establishing and validating one order of marketization against another. For it is not just the biography of the artwork that the primary market tries to control but also, of course, that of the artist, the dealer-gallerists themselves and, primarily, the collector. Though these have been the main characters of the discussion so far, the importance of the curator and the critic (and to a lesser extent the academic too) must not be neglected. For the latter two articulate and make explicit how such art is full of socio-cultural or, less generally, biographical content. In any case, the curator and the critic attest to the work as having stronger or weaker cultural interests independent of market value, that is: as 'really' being about anything but the price, helping to ensure that the artwork does not 'get in touch with money again'. This is a crucial and decisive role in resisting and defying the mono-determination of neo-liberal market ideology which takes price as its organizing ideological and operational principle. But, again, this is hardly a novel conclusion: with respect to market formations, such a defiance and objection is pretty much the received understanding of what critique is often held to be 
(almost irrespectively of what the art actually is, unless its subject matter is explicitly price setting or the commodification of price - though even in such cases it is the concept and meaning of price and marketization rather than the price of the work itself that tends to be the focus of what is called the 'artistic' or critical interest).

The key characteristics of art's critical claims will be taken up in a moment. Before doing so, the two-fold legitimation function of critique in the primary market must be noted: first, and pragmatically, critique is immediate and content-specific, articulating the interests of this or that artpractice, articulating such-and-such concerns and giving them wider pertinence (this does not require such critique to be read or paid attention to, only that it should be extant). This is the familiar and well-established role of art-criticism, theory and artworks as themselves a critical undertaking. It is the mark of non-commodification, non-marketization, morally organized care; a sentiment that things beyond cash-flow matter, an index and demonstration of passions and ideas irreducible to capital accumulation, etc. Second, as such, critique serves to distinguish between the interests of the primary and secondary markets. It assures the former that its interests are not those of capital accumulation or art qua market-value but are directed against the artwork 'getting in touch with money again'. These are not dissociable roles. The first is the particular instance of the second, more general operational feature facilitating the distinguishing of kinds of markets and their interests not only analytically but in fact. In this operational role, the content and sense of the particular moments of critique are of little significance. It makes little odds what is being generated in the particular moments of critique, only that it is manifest or, at least, purported. The current proliferation and simultaneous immiseration of specific, trenchant critique - not least through its continued confusion with art-history are appropriate to this operational role in which it revels and is strongly avowed, if not celebrated. That critique is weak, slight, unambitious, easily accommodated, etc., is of no concern; only the mark, sign or claim of critique is necessary.

It is not then a question of art being critical in its hostility against markets altogether (art versus commerce, quality versus quantity), but of one kind of market in critical relation to another (primary art-market versus neoliberal markets). The rhetoric and operational justifications of the critical claims of art not only protect and serve the primary market. Critique is also served by the primary market. The reversibility between the justifications of the primary market and art's critique propose an identification: the primary market now holds itself to be not just integral to art's critical claims nor just a condition of critique, but is moreover itself an instance of critique. The struggle of critique takes place at the level of kinds of markets rather than the particular content of this or that critical moment because what contemporary art acts out through the primary market's control of contemporary art (intellectual-amorous affirmation) is a moral claim against how power is re-organized with the larger neo-liberal transformation of markets (wealth power). That is, as art becomes an alternative asset class, the primary art market determines itself as inherently critical because it is moral in its care ('people before profit', 'biographies before prices'), this care being organized around how the art and the collector reflect and embody each other's 
values, one through the critical claims of art and what is 'interesting' or of 'quality' - 'making people think', as it is frequently put - the other through the expenditure of their private wealth.

Contemporary art (insofar as it is organized, determined, distributed and based in the primary market) no longer opposes 'its' market but only supports it through its critical claims - and especially when it claims to oppose 'the market'. Put otherwise, as a tactic in a strategy of struggles by distinct markets for control or not over biographies of artwork and, more particularly, price-setting, contemporary art is a point of struggle between two deployments of private wealth and the restructuring of markets. Critique in contemporary art is only an aspect of a conflict in not just how to accumulate, but in what it is to accumulate. The following paragraphs examine the consequences of the identification of critique and the primary art market, of the primary market as critique.

The preceding re-determination of the 'task' of critique in the practical institution and decision-making processes of contemporary art returns us to the question of its specific claims and declared ambitions. That is, the question now is: what is signalled by the division in kinds of wealth generation indexed by critique with regard to larger ideological formations and reformations of capital accumulation? Furthermore, since critique serves a certain formation of capital accumulation, what does critique in fact assert in these conditions? These questions are taken up through Luc Boltanski and Ève Chiapello's theory of a 'new spirit of capitalism' (2005), a primary feature of which is the importance of critique - and in particular what they call 'artistic critique' - in re-shaping and generating capital accumulation since the mid-1960s (the period when contemporary art emerged distinctly from the concerns of modern art). Examining Boltanski and Chiapello's account of the importance of artistic critique in the re-organization of capital accumulation and labour will lead us to see more exactly how and why the primary market legitimates capital accumulation in general and neo-liberalism in particular even if, as seen, its struggle is putatively against the latter's dominance.

As the term 'spirit' indicates, Boltanski and Chiapello's primary concern is not the material processes of capitalism per se, understood in the first instance as a system of production and circulation of wealth, the organization of labour and the re-investment of wealth back into that system in order to accumulate yet greater profits. Rather, the object of their study is the justification or legitimating ideology for that process of accumulation and how it shapes and organizes the latter. The spirit of capitalism is

the set of beliefs associated with the capitalist order that helps to justify this order and, by legitimating them, to sustain the forms of action and predispositions compatible with it. These justifications, whether general or practical, local or global, expressed in terms of virtue or justice, support the performance of more or less unpleasant tasks and, more generally, adhesion to a lifestyle conducive to the capitalist order.

(2005: 10-11)

The issue here is how capitalism as a material process and determination of forms of life comes to be socially and morally sanctioned when it cannot 
establish these grounds in itself since, as material-economic operation, it is oriented only towards capital accumulation rather than any kind of justice. Such accumulation-techniques must be socially warranted and justified if those who are integral to capitalism yet are not 'its privileged beneficiaries' (2005: 18) are to not only withstand it but to acquiesce in sustaining it by working in and for it, and even identifying themselves with it in pursuing their ambitions through it. Boltanski and Chiapello have no time for a 'false consciousness' model of acquiescence to capitalism and locate the sanctions for the system of production and wealth generation in quotidian and personal interests of workers and managers looking to secure good schools for their children, promotion, health care for their parents, safe housing, etc. - in general, in the wish to 'do better' for themselves, their nearest, and others. Workers in capitalism are, Boltanski and Chiapello remind us, also moral agents. The interest in such codes of moral justification is here more parochial: the distinction identified above between markets is precisely between the primary market as a socio-morally determined basis for exchange and circulation and the secondary market for which art is predominantly an asset for wealth generation with no justification beyond price. In Boltanski and Chiapello's terms, the primary market can be understood to operate in terms of a spirit of capitalism while the secondary market functions in terms of direct capital accumulation. Accounting for the distinction between markets in terms of a spirit of capitalism will enable us to understand how the primary market in its reliance on critique serves to legitimize the prevalent social re-organization of capital accumulation by neo-liberal marketization even though it may disparage the encroachment of the latter on its field of activity. Critique can then be identified as an alibi for marketization qua neoliberal capital accumulation. On this basis, the heightened cultural and market interest in contemporary art at precisely the moment when neo-liberalism has been a dominant economic model (1990s-2008) and in the places where it has become prominent (OECD countries and what are called the emerging markets) would have to be understood as something other than just an effect of inflated asset prices, large flows of liquidity, or the mystification of somehow 'interconnected' aspects of a generalized culture of risk.

Critique is the leading concern not only for the present argument but also for Boltanski and Chiapello themselves. Their main thesis is straightforward: social-moral justifications for capitalism are found by looking to those who are antagonistic to it. Capitalism they say 'needs its enemies, people whom it outrages and who are opposed to it, to find the moral supports it lacks and to incorporate mechanisms of justice whose relevance it would otherwise have no reason to acknowledge' (2005: 27). One recent example of this is the incorporation of environmental concerns into core industries: activism against the environmental damage caused by manufacturing, energy and transport sectors has pushed/led them to refashion their processes and output (for example, renewable and non-carbon emitting energy), opening new channels of capital investment and accumulation that is, to act morally and to become more tolerable. More generally, the spirit of capitalism is a 'critical fulcrum' in capitalism: it justifies various modes of capitalism and no less makes it 'possible to condemn the discrepancy between the concrete forms of accumulation and normative conceptions 
3. In these terms Jacques Rancière's contribution is to locate the interests of social critique as being identified through artistic critique - or what Rancière calls art in the aesthetic regime by its effectuation of equality through its redistribution of the sensible (see for example The Politics of Aesthetics (2004)). Though Rancière thus seems to overcome the tension between artistic and social critique, it is nonetheless the case that the terms by which art in the aesthetic regime effectuates its equalizations are primarily formal, material, sensorial and not through the identification or presentation of concerns that could be readily identified with the preoccupations of social critique. of the social order' (2005: 25), forcing their restructuring. Boltanski and Chiapello schematize the motivating factors for this discrepancy - which requires a moral recourse - proposing that the critique of capitalism stems from four sources of 'indignation': (i) disenchanted and inauthentic existence at all levels; (ii) oppression of social or personal freedom, creativity and autonomy because of the impersonal force of overwhelming market power and alienated or disciplined labour; (iii) poverty and social and economic inequality; and (iv) the privileging private interests over public concerns and solidarity, encouraging opportunism (2005: 37). While various shapes and formations of capitalism as a material process give rise to 'indignation' with it along these broad lines, the overall point is that the critique that grows from indignation with capitalism is a rejoinder to it. In this formulation, critique is always a critique of capitalism and, insofar as it stems from the particular forms of work and life it requires at any historical moment, critique emanates from capitalism.

Schematized into the four categories just noted, it becomes apparent that these sources of indignation and the critiques they give rise to are incoherent and even antagonistic to one another. Boltanski and Chiapello distinguish them into two meta-categories: on the one hand, social critique, which denounces the inequality and self-interest promoted by capitalism; on the other, artistic critique, which denounces the inauthenticity and oppression of capital (2005: $38 \mathrm{ff}$.). If it was social critique that justified and in some ways led the transition from industrial to a managerial capitalism (bureaucratic capitalism) concomitant with welfarism in the mid-twentieth century period, Boltanski and Chiapello propose that it is now artistic critique that has gained prominence. Artistic critique counterpoints the fixity and stability of historical capitalist processes and the interests of social critique with the freedom of art(ists), the rejection of material or spatiotemporal fixing or many other attachments, and the rejection of piety towards work as labour (rather than play), reaching a heightened expression around May 1968. ${ }^{3}$ And it is artistic critique that for Boltanski and Chiapello now constitutes the spirit, a new spirit, of capitalism. They come to this conclusion through a sobre analysis of management textbooks in France from the late 1980 s to mid-1990s. What they find in this literature is

an echo of the denunciations of hierarchy and aspirations to autonomy that were insistently expressed at the end of the 1960 s and in the 1970s. [...] The qualities that are guarantees of success in this new spirit - autonomy, spontaneity, rhizomorphic capacity, multitasking (in contrast to the narrow specialisations of old division of labour), conviviality, openness to others and novelty, availability, creativity, visionary intuition, sensitivity to differences, listening to lived experiences, being attached to informality and the search for interpersonal contacts - these are taken directly from the repertoire of May 1968.

(2005: 97)

These 'qualities' are accompanied by a denunciation of

prefabricated needs, the ascendancy of advertising and marketing, the 'crumbling away of human values under the influence of exchange mechanisms', 
the reign of the quantitative (as opposed to the qualitative), the standardisation of goods in mass production, the domination of appearances, the tyranny of [established status], the invasion of useless, ugly, ephemeral objects and so on.

(2005: 99)

Such claims and denunciations can now be heard at all levels in the overwhelming emphasis in aspirations directed towards individuality, creativity, autonomy and self-discovery (from the management of professional life to home decorating). And though it is modelled on the Baudelerian figure of the bohemian, such claims are still espoused under the guise of different figures and discourses in, and as the vital interest of, contemporary art now not least as the general characteristic and postulate of critique. Boltanski and Chiapello's principal argument is however not just that such claims can be found in managerial practices of capitalism since the mid-late $1980 \mathrm{~s}$ onwards but that, moreover, such critiques of a certain configuration of work, production, accumulation now justify that order of capitalism since they make it viable:

these themes, which in the texts of the May movement were [and, as the convivial assumption for artists' culture today, still are] combined with a radical critique of capitalism (particularly the critique of exploitation), and the proclamation of its immanent end, are often to be found in the neo-management literature... represented as objectives that are valid in their own right, and placed in the service of forces whose destruction they were intended to hasten.

(2005: 97)

Capitalism takes on the mantle of artistic critique for itself. With that, critique is disarmed (Boltanski and Chiapello 2005: 34) and artists - especially critically engaged artists - are the heroes of the new spirit of capitalism. The problem here for any model which still asserts the oppositionality of artistic critique to capitalism and its spirits is that such 'artist-cultural' modes of practice do not just lead the new spirit of capitalism, giving it its contemporary 'salience and appeal' (2005: 99), but now also enhance and serve the process of capitalist accumulation as such, at the cost of a corrosion of organizational security ('precarity'). If justice is to be understood as the realization of equality and the public good (as per 'social critique'), what justice artistic critique has remains only 'implicit' rather than explicit.

The identification of the primary market as itself an instance of critique can then be understood without contradiction or paradox. It is an instance of the artistic critique that is at once and as such the new spirit of capitalism (correlative to the burgeoning dominance of neo-liberalism as a model of economic operation). And what is perhaps novel in the formation of the new spirit of capitalism through artistic critique as it is instantiated and figured by the primary market (rather than the 'themes...valid in their own right' in the management literature Boltanski and Chiapello analyse) is that the legitimacy of capital accumulation and marketization granted to capitalism is not made through any external principle (Protestantism for earlymodern capitalism, the family or the public virtue of paternalism in bourgeois capitalism, large-scale problem-solving for bureaucratic capitalism). Rather, 
the primary market demonstrates that the validation and legitimacy of capitalism, its spirit, is now itself a market. If the primary market is an instance of artistic critique in its struggle against the price-setting machinations of the secondary market and guarantor of the particular instances of artistic critique (manifest as the several and various practices that are the putative concern of its activity), then that market is itself a legitimation for capital marketization. That is, the primary market shows that markets can and do care, that they can be moral, affectively sensitive, intellectually demanding. With the primary market, the spirit of capitalism is immanent to marketization. Put otherwise, capital accumulation can justify and legitimize itself by an appeal to market activity itself. The interest in major corporations - especially in finance - in supporting contemporary art and being seen to be doing so can be understood here without contradiction in critique or in their support. More generally, the market holds the terms of its social legitimacy within itself, and the primary market proves as much in its support of critique.

The primary market demonstrates the legitimacy and care of markets when marketization is naturalized and valorised in neo-liberalism not despite but because of their different kinds of market operation. In this sense, critique is now not just the alibi of capitalism but an instance of contemporary capitalism's self-legitimation and social justification and, as such, is welcomed by it. In its interest and advocacy of critical art, the primary market then extends and accelerates the critique of bourgeois and managerial forms of life (the preceding moments of capital and its attendant spirits), the state as oppressive or restrictive of individual liberties and expressions, and of the capitalized organization of labour and accumulation. In doing so, it feeds and justifies the reorganization of capitalism towards more precarious, unstable and flexible kinds of labour and - as the liquidity shortages of 2008 have shown - of capital itself. While the grip of the primary market over production, exhibition and circulation of contemporary art and its seriousness is threatened by the encroaching power of the secondary market, it is the very instability and precariousness, the inherent non-integrity, of the secondary market with its emphasis on accumulation rather than critique that is in fact justified by the primary market in its claims to do justice to art(ists). This is a claim that demonstrates that markets can care, and that such care is not a condition of resistance or exodus from accumulation (as a mode of immaterial labour, say) but inextricably tied to its future production. The bid of care into the future characteristic of the primary market which is articulated and made precise through and as critique is at once a bid to secure the dominance of capital accumulation in general.

\section{References}

Boltanski, Luc and Chiapello, Ève (2007 [1997]), The New Spirit of Capitalism (trans. Gregory Elliot), London: Verso.

Boroff, Philip (2008), 'Sotheby's Discloses \$15 Million Loss on Guarantees in October', Bloomberg Muse, www.bloomberg.com/apps/news?pid=20601120\& sid=ajT2WG PeylOI\&refer=muse. Accessed 24 October 2008.

Campbell, Rachel (2008), 'Art as an Alternative Asset Class', LIFE Research Paper No. WP 05-001, Maastricht: Maastricht University, ssrn.com/abstract $=675643$. Accessed 10 October 2008. 
Euromoney Training (2008), 'Investing in Art: A New Alternative Asset Class', www.euromoneytraining.com/default.asp? Page $=16 \&$ productid $=4537$. Accessed 10 October 2008.

Foucault, Michel (1978 [1976]), The History of Sexuality Vol.1: An Introduction (trans. Robert Hurley), London: Penguin.

(2007 [2004]), Security, Territory, Population. Lectures at the Collège de France 1977-1978 (trans. Graham Burchell), Basingstoke: Palgrave Macmillan.

Gerlin, Melanie (2007), 'Warning Signs?', The Art Newspaper, September, London: Umberto Allemandi \& Co., p. 1.

Rancière, Jacques (2004), The Politics of Aesthetics (trans. Gabriel Rockhill), London: Continuum.

Reyburn, Scott (2008), 'Dennis Hopper, Arnault Browse FIAC as Galleries Fight for Sales', Bloomberg Muse, www.bloomberg.com/apps/news?pid=20601120\&sid= akQouCygaSUM\&refer=muse. Accessed 24 October 2008.

and Katya Kazakina (2008), 'Shocked Collectors Seek Bargains as Frieze Buying Stampede Ebbs', Bloomberg Muse, www.bloomberg.com/apps/news?pid= newsarchive\&sid=av2V6Tf7Scrg. Accessed 24 October 2008.

Velthuis, Olav (2005), Talking Prices: Symbolic Meanings of Prices of the Market for Contemporary Art, New Jersey: Princeton University Press.

(2008), 'Accounting for Taste: The Economics of Art', Artforum International, April, New York: Artforum, pp. 305-09.

\section{Suggested citation}

Malik, S. (2008), 'Critique as alibi: moral differentiation in the art market', Journal of Visual Arts Practice 7: 3, pp. 283-295, doi: 10.1386/jvap.7.3.283/1

\section{Contributor details}

Suhail Malik is Reader in Critical Studies in the Department of Art, Goldsmiths, London, where he is also Director of The Political Currency of Art Research Group. Malik has written on the market and critical conditions of contemporary art, and on current technical and political theory, several catalogue essays, and is currently working on a philosophy of American power.

Contact: Art, Goldsmiths, Lewisham Way, London SE14 6NW.

E-mail: s.malik@gold.ac.uk 
Copyright of Journal of Visual Art Practice is the property of Intellect Ltd. and its content may not be copied or emailed to multiple sites or posted to a listserv without the copyright holder's express written permission. However, users may print, download, or email articles for individual use. 